\title{
The neuroprotective effects of electrolyzed reduced water and its model water containing molecular hydrogen and Pt nanoparticles
}

\author{
Hanxu Yan', Taichi Kashiwaki ${ }^{2}$, Takeki Hamasaki ${ }^{2}$, Tomoya Kinjo ${ }^{1}$, Kiichiro Teruya ${ }^{1,2}$, Shigeru Kabayama ${ }^{3}$, \\ Sanetaka Shirahata ${ }^{1,2^{*}}$
}

From 22nd European Society for Animal Cell Technology (ESACT) Meeting on Cell Based Technologies Vienna, Austria. 15-18 May 2011

\section{Background}

Human brain is the biggest energy consuming tissue in human body. Although it only represents $2 \%$ of the body weight, it receives $20 \%$ of total body oxygen consumption and $25 \%$ of total body glucose utilization. For that reason, brain is considered to be the most vulnerable part of human body against the reactive oxygen species (ROS), a by-product of aerobic respiration. Oxidative stress is directly related to a series of brain dysfunctional disease such as Alzheimer's disease, Parkinson's disease etc. Electrolyzed reduced water (ERW) is a functional drinking water containing a lot of molecular hydrogen and a small amount of platinum nanoparticles (Pt NPs, Table 1). ERW is known to scavenge ROS and protect DNA from oxidative damage [1]. We previously showed that ERW was capable of extending lifespan of Caenorhabditis elegans by scavenging ROS [2]. Molecular hydrogen could scavenge ROS and protected brain from oxidative stress [3]. Pt NPs are also a new type of multi-functional ROS scavenger [4].

\section{Materials and methods}

In this research, we used TI-200S ERW derived from 2 $\mathrm{mM} \mathrm{NaOH}$ solution produced by a batch type electrolysis device and model waters containing molecular hydrogen and synthetic Pt NPs of 2-3 nm sizes as research models of ERW to examine the anti-oxidant capabilities of ERW on several kinds of neural cells such as PC12, N1E115, and serum free mouse embryo (SFME) cells. We pretreated the ERW and $200 \mu \mathrm{M}$

\footnotetext{
* Correspondence: sirahata@grt.kyushu-u.ac.jp

'Graduate School of Systems Life Sciences, Kyushu University, 6-10-1

Hakozaki, Higashi-ku, Fukuoka 812-8581, Japan

Full list of author information is available at the end of the article
}

$\mathrm{H}_{2} \mathrm{O}_{2}$ and examined the neuroprotective effects of ERW on PC12, N1E115 and SFME cells, using WST-8 method. We also examined the intracellular ROS scavenging effects of ERW on N1E115 cells after pretreated cells with ERW and $\mathrm{H}_{2} \mathrm{O}_{2}$ using DCFH-DA. We checked the protective effects of ERW on mitochondria and cytoplasm by Rh123 and Fuo-3 AM stain. We also examined the ATP production of SFME cells after pretreated with ERW and $\mathrm{H}_{2} \mathrm{O}_{2}$ by Bioluminescence Assay Kit. Finally, we used dissolved hydrogen $(\mathrm{DH})$ and $\mathrm{Pt}$ NPs as research models to examine their neuroprotective effects.

\section{Results}

ERW significantly reduced the cell death induced by $\mathrm{H}_{2} \mathrm{O}_{2}$ pretreatment (Figure 1). ERW also scavenged the intracellular ROS and prevented the decrease of mitochondrial membrane potential and ATP production induced by ROS. We also examined the neuroprotective effects of molecular hydrogen and Pt NPs and showed that both molecular hydrogen and Pt NPs contributed to the neuroprotective effects of ERW.

\section{Conclusion}

The results suggest that ERW is beneficial for the prevention and alleviation of oxidative stress-induced human neurodegenerative diseases.

\footnotetext{
Author details

${ }^{1}$ Graduate School of Systems Life Sciences, Kyushu University, 6-10-1 Hakozaki, Higashi-ku, Fukuoka 812-8581, Japan. ${ }^{2}$ Department of Bioscience and Biotechnology, Faculty of Agriculture, Kyushu University, Fukuoka 8128581, Japan. ${ }^{3}$ Nihon Trim Co. Ltd., 1-8-34 Oyodonaka, Kita-ku, Osaka 5310076, Japan.
} 
Table 1 Characteristics of the water samples.The characteristics of water samples were determined immediately after the preparation of ERW. ERW, electrolyzed reduced water; CW, activated charcoal-treated water. The pH values were shown as average \pm standard deviation $(\mathrm{N}=5)$. The values of $\mathrm{DH}, \mathrm{DO}$ and Pt NPs were shown the minimum and maximum values after 5 independent measurements.

\begin{tabular}{|c|c|c|c|c|}
\hline & $\mathrm{MQ}(\mathrm{NaOH})$ & TI-200 ERW & TI-9000 CW & TI-9000 ERW \\
\hline$\overline{\mathrm{pH}}$ & $11.3 \pm 0.1$ & $11.6 \pm 0.1$ & $7.9 \pm 0.1$ & $9.6 \pm 0.2$ \\
\hline Dissolved Hydrogen (mM) & 0 & $0.2-0.45$ & 0 & $0.1-0.25$ \\
\hline Pt NPs (nM) & 0 & $0.5-12.8$ & 0 & $0-3.6$ \\
\hline Redox potential value (mV) & +350 & -659 & - & - \\
\hline
\end{tabular}
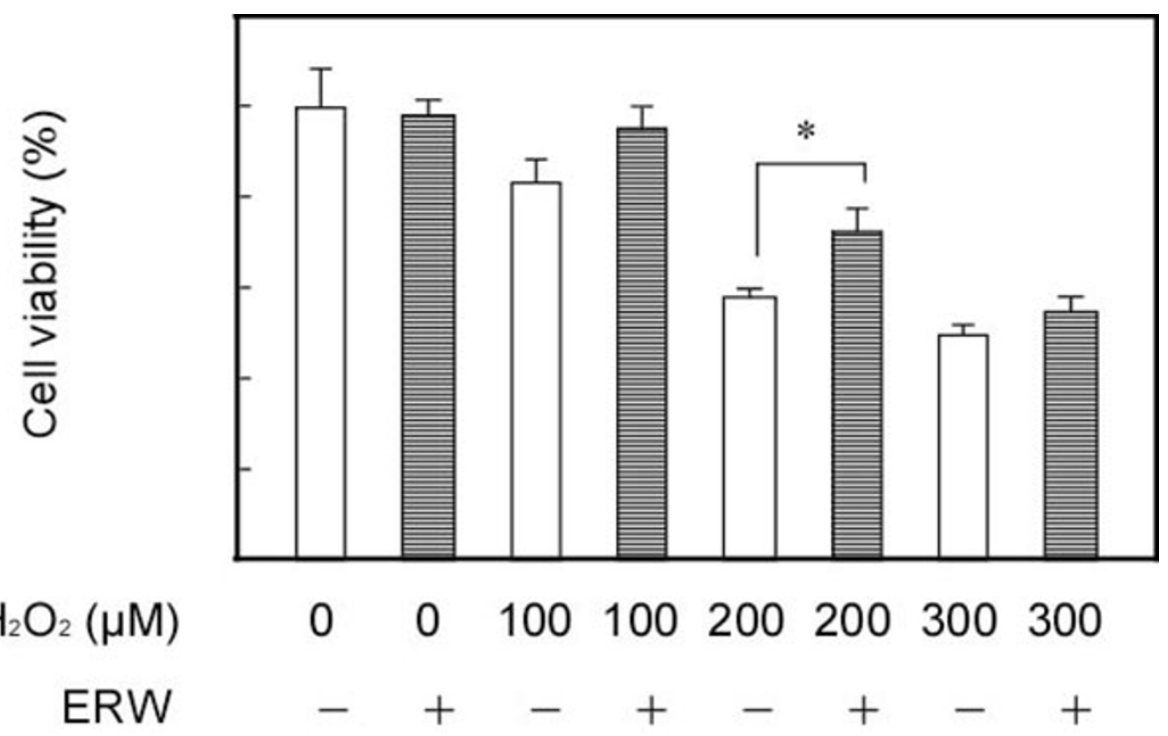

Figure 1 Protective effect of ERW on $\mathrm{H}_{2} \mathrm{O}_{2}$-induced neuroblastoma $\mathrm{N} 1 \mathrm{E} 115$ cells death. Cells were treated with water samples (ERW and control ultrapure water with same $\mathrm{pH}$ with ERW) and $200 \mu \mathrm{M} \mathrm{H}_{2} \mathrm{O}_{2}$ for $24 \mathrm{~h}$. Cell viabilities were assayed by WST-8 method. $\mathrm{N}=3,{ }^{*} \mathrm{p}<0.05$.

Published: 22 November 2011

\section{References}

1. Shirahata S, Kabayama S, Nakano M, Miura T, Kusumoto K, Gotoh M

Hayashi H, Otsubo K, Morisawa S, Katakura Y: Electrolyzed-reduced water scavenges active oxygen species and protects DNA from oxidative damage. Biophys Biochem Res Commun 1997, 234:269-274.

2. Yan $\mathrm{H}$, Tian $\mathrm{H}$, Kinjo $T$, Hamasaki T, Tomimatsu K, Nakamichi N, Teruya $\mathrm{K}$, Kabayama S, Shirahata S: Extension of the lifespan of Caenorhabditis elegans by the use of electrolyzed reduced water. Biosci Biotech Biochem 2010, 74:2011-2015.

3. Ohsawa I, Ishikawa M, Takahashi K, Watanabe M, Nishimaki K, Yamagata K, Katsura K, Katayama Y, Asoh S, Ohta S: Hydrogen acts as a therapeutic antioxidant by selectively reducing cytotoxic oxygen radials. Nature Med 2007, 13:688-694.

4. Hamasaki T, Kashiwagi T, Imada T, Nakamichi N, Aramaki S, Toh K, Morisawa S, Shimakoshi H, Hisaeda Y, Shirahata S: Kinetic analysis of superoxide anion radical-scavenging and hydroxyl radical-scavenging activities of platinum nanoparticles. Langmuir 2008, 24:7354-7364.

doi:10.1186/1753-6561-5-S8-P69

Cite this article as: Yan et al:: The neuroprotective effects of electrolyzed reduced water and its model water containing molecular hydrogen and Pt nanoparticles. BMC Proceedings 2011 5(Suppl 8):P69.

Submit your next manuscript to BioMed Central and take full advantage of:

- Convenient online submission

- Thorough peer review

- No space constraints or color figure charges

- Immediate publication on acceptance

- Inclusion in PubMed, CAS, Scopus and Google Scholar

- Research which is freely available for redistribution 